\title{
Influence of different digital diseases in lameness of dairy cows in southwest of the state of Goiás*
}

\section{Influência de diferentes enfermidades digitais na claudicação de vacas leiteiras no sudoeste de Goiás}

\author{
Rogério Elias Rabelo, ${ }^{* *}$ Valcinir Aloísio Scalla Vulcani, ${ }^{* *}$ Fabiano José Ferreira de Sant'Ana, ${ }^{* *}$ Caroline Rocha de Oliveira \\ Lima, ${ }^{* * * *}$ Andressa Sabine Rabbers, ${ }^{* * * * *}$ Panmera Almeida Helrigel, ${ }^{* \star \star * * *}$ Márcia Dias ${ }^{\star * * \star \star * *}$
}

\begin{abstract}
The type of podal lesion varies according to the disease and several factors may be considered as determinants of high prevalence in breeding stocks. It severity is often attributed to the extension of the lesion and the impairment of structures that compose the hoof. However, clinically, it is noted that digital lesions that appear to a have mild or moderate tissue impairment area are identified as causing severe lameness in cattle. It is worth noting that the economic losses caused by this disease often go unnoticed by producers, a fact that is worrying, since the values are generally high. The objective with this paper was the analysis of epidemiological data of podal diseases in dairy cows, evaluating the influence of the different types and severity of those lesions, correlating them to the type and degree of lameness. The work was conducted in the Southwest of the State of Goiás in ten dairy farms and 190 Holstein, Jersey and mixed breed cows affected by different digital lesions were used. Scores for lameness and podal diseases were established. The data allowed to point out that digital dermatitis was the disease with higher incidence and the right pelvic limb, the most affected. In addition, digital lesions that are usually considered severe are not always responsible for severe lameness.
\end{abstract}

Keywords: digital dermatitis, diseases of cattle, podology.

\section{Resumo}

Os tipos de lesões podais variam de acordo com a enfermidade que está acometendo o animal e são considerados diversos os fatores que determinam sua a alta prevalência no rebanho. A severidade geralmente está atribuída ao grau de extensão da lesão e aos danos às estruturas do casco. Porém, verifica-se clinicamente que lesões digitais pouco profundas têm causado claudicações severas em bovinos. Ressalte-se, ainda, que os prejuízos econômicos causados por essa enfermidade muitas vezes passam despercebidas pelos produtores, fato esse preocupante, já que os valores geralmente são altos. Portanto, o objetivo com este estudo foi realizar uma análise epidemiológica das enfermidades podais em bovinos leiteiros, avaliando a influência dos diferentes tipos e severidade das lesões, correlacionando-os ao tipo e grau de claudicação. O estudo foi conduzido na região sudoeste do estado de Goiás, em dez granjas leiteiras, utilizando 190 animais das raças Holandesa, Jersey e animais mestiços portadores de diferentes lesões digitais. Foram estabelecidos escores para os graus de claudicação e enfermidades podais. Os resultados mostraram que a dermatite digital foi a enfermidade de maior incidência e o membro pélvico direito o mais acometido. Soma-se a isso, também, que lesões podais consideradas graves nem sempre são responsáveis por claudicações severas.

Palavras-chave: dermatite digital, doenças de bovinos, podologia.

\section{Introduction}

Diseases affecting the hoofs of cattle are presented as one of the main multifactorial etiology disorders that affect dairy animals. Aspects such as the racial characteristics of the animals, nutritional challenges, inadequate facilities, management errors, and especially, negligence of the biosecurity measures are considered the most important aspects for the incidence of podal diseases in cattle (Blowey e Weaver, 2006; Rabelo et al., 2006; Franck et al., 2008; Rodrigues et al., 2010). In Brazil, these diseases occur in several regions, causing significant damages to breeding farms (Borges et al., 1992; Molina et al., 1999; Cruz et al., 2001; Silva et al., 2001; Souza et al., 2007).

*Recebido em 14 de agosto de 2013 e aceito em 20 de dezembro de 2013.

**Professor - Veterinary Medicine Department - Federal University of Goiás, Campus of Jataí, Jataí, Goiás, Brazil.

***Professor - Veterinary Pathology Department - Brasília University, Brasília, Brazil.

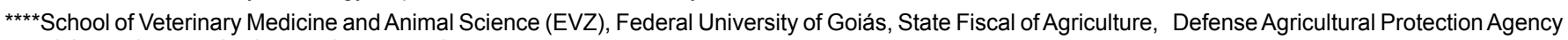
of Goiás State (AGRODEFESA) Jataí, Goiás, Brazil.

*****Veterinary Medicine Residence Program - Federal University of Goiás, Campus of Jataí, Jataí, Goiás, Brazil.

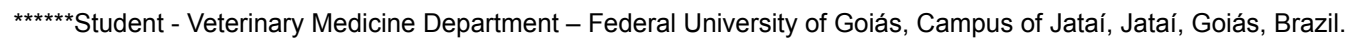

******Professor - Zootechnical Department - Federal University of Goiás, Campus of Jataí, Jataí, Goiás, Brazil. 
Depending on the digital disease, in many situations, the economic impact caused is noticed slowly and the respective damages do not impress the breeders as much as those that occur in conditions that result in death. However, losses arising from lameness have a significant daily cost, due to pain, inability or difficulty of the animal to remain standing or even move to feed, with consequent productive and reproductive drop, possibility of contagion to other individuals, as well as repeated treatments and relapses. Thus, losses may accumulate in such a way that their sum, in some cases, gets close to or even exceeds the intrinsic value of the cattle. Thus, in many situations, the economic feasibility of this production system seems questionable (Silva et al., 2005; Silveira et al., 2009; Rodrigues et al., 2010).

The type of podal lesion varies according to the disease. It severity is often attributed to the extension of the lesion and the impairment of structures that compose the hoof (Vermunt et al., 1995; Smith, 2001; Greenough, 2007). However, clinically, it is noted that digital lesions that appear to have a mild or moderate tissue impairment area are identified as causing severe lameness in cattle (Rabelo et al., 2009). In this sense, there is disagreement in the literature about the type of lesion, anatomic location and the hoof structure(s) affected that initiate the most painful sensation in cattle and, therefore, more pronounced lameness.

The objective with this paper was the analysis of epidemiological data of major hoof diseases that affect dairy cattle bred in the Southwest of the State of Goiás, evaluating the influence of the different types and severity of those lesions, correlating them to the type and degree of lameness presented by the injured animal.

\section{Material and methods}

The study was conducted in ten properties destined to the exploitation of dairy cattle in the municipality of Jatai/GO, ${ }^{1}$ from April 2010 to June 2011, being the research project submitted to and approved by the Animal Research Ethics Committee of the Federal University of Goiás, according to protocol 112/10. For the study 190 Holstein, Jersey and mixed (Bos indicus/Bos taurus) breed lactating cows were used, with ages ranging from 36 to 70 months, affected by different digital diseases.

In all properties evaluated in this study the dietary and nutritional management was given twice daily and consisted, during the rainy season, of rotational grazing and supplementation specific to each category of animal, according with the production of each batch. In the dry season, the animals were subjected to semiconfined system, receiving corn silage and supplementation with ration, also according to the production of each lot, in the form of Total Mixed Ration.

All 190 injured animals were laming and were submitted to the specific examination of the locomotor system (Radostits et al., 2002), where lesions were identified and evaluated clinically, following a methodology similar to those described in the literature (Demirkan et al., 2000; Romani et al., 2004; Greenough, 2007; Castro et al., 2008). Prior to the diagnosis of podal diseases present in each animal, as well as to the establishment of the disorder severity, the animals were submitted to the assessment of the type and degree of lameness. Such protocol was conducted in order to avoid possible interferences in lameness after the podal examination for diagnostic purposes.

\footnotetext{
${ }^{1}$ State of Goias
}

The criterion for determining the type and the scores of lameness was based on the observation of the injured animals in quadrupedal position, both at rest and during movement, being established to locomotion a five-minute period as a parameter of analysis to evaluate the lameness score. This score ranged from zero to four (Greenough, 2007), as described in Table 1.

Table 1: Lameness scores for the identification of podal lesions in dairy cattle in the municipality of Jataí/GO from April 2010 to June 2011

\begin{tabular}{cl}
\hline Score & \multicolumn{1}{c}{ Clinical Signs } \\
\hline 0 & $\begin{array}{l}\text { Regular posture with straight back line in quadrupedal } \\
\text { position and locomotion, firm steps with correct } \\
\text { distribution of weight and supports. }\end{array}$ \\
1 & $\begin{array}{l}\text { Regular posture in quadrupedal and slightly arched } \\
\text { position during regular locomotion and supports. }\end{array}$ \\
2 & $\begin{array}{l}\text { Arched posture in quadrupedal position and locomotion, } \\
\text { slight change of steps. }\end{array}$ \\
3 & $\begin{array}{l}\text { Body arching in quadrupedal position and locomotion, } \\
\text { evident asymmetry of the support sparing limbs, with } \\
\text { shorter support time of injured limb(s). } \\
\text { Inability to support or sustain the weight of the injured } \\
\text { limb(s), reluctance or refusal to locomotion. }\end{array}$ \\
\hline
\end{tabular}

Source: Adapted from Greenough (2007)

After the type and degree of lameness were evidenced, scores were settled concerning the severity according to the characteristic of the disease to be diagnosed. For this procedure, the animals were previously sheltered in a specific containment stock pen. The ends of the limbs were sanitized to remove excess of dirtiness, followed by antisepsis with povidone-iodine ${ }^{2}$ based solution. In some animals, taking into account the need to curette areas of the hoof to evidence better the type and severity of the lesion, it was necessary to carry out an infiltration local block, using $2 \%$ based lidocaine anesthetic. ${ }^{3}$

After this step, the lesions were measured to assess clinical scores. These lesions were classified as mild (E1), moderate (E2) and severe (E3). Early stage lesions whose tissue impairment was limited to the interdigital area skin of the region between the heels and coronary corium which presented erosive appearance, irregular edges, reddish core, and which may present corneas papillae and maximum diameter of three centimeters were considered mild. The lesions on the sole, such as double sole and hematomas, on the toes and white line, which presented extensions smaller than one centimeter, were also allocated in this score. The moderate score, in addition to the disorders described above, included the animals that presented focal areas of necrosis, especially at the edges of wounds and partial impairment of the hoof, heels and sole, however, not damaging the laminar corium.

Concerning the lesions on the sole and white line, those that presented extension larger than one and smaller than two centimeters were included in this score. The lesions classified as severe included impairment of the sole or white line with

\footnotetext{
${ }^{2}$ Riodeine - Rioquímica Indústria Farmacêutica Ltda., São José do Rio Preto, SP

${ }^{3}$ Lidovet - Laboratório Bravet Ltda., Rio de Janeiro, RJ
} 
extension larger than two centimeters, presence of necrosis, erosion of the heels, considerable impairment of abaxial and axial walls of the hoof, presence of myiasis and, in many cases, growth of tissue with proliferative (verrucous) aspect, in addition of phalangeal fractures.

The scores of podal diseases diagnosed were related to the anatomical hoof region affected and to the type and degree of lameness. The Chi-square test was used to compare the frequencies of podal lesions and the frequency of impairment of the right and left thoracic or pelvic limbs. The Spearman correlation was used to analyze the relationship of lesion severity and lameness degree presented by injured animals (Sampaio, 2007). SAS 9.0 (2002) program was used in all analysis of this study, considering $5 \%$ of probability.

\section{Results and discussion}

Among the clinical cases studied, the main diseases diagnosed were digital dermatitis $(45 / 190)(23.7 \%)$, septic pododermatitis $(24 / 190)(12.6 \%)$, double sole (23/190) (12.1\%), tiloma (17/190) $(8.9 \%)$, interdigital dermatitis $(15 / 190)(7.9 \%)$, sole ulcer $(14 / 190)$ $(7.4 \%)$, sole hematoma $(13 / 190)(6.8 \%)$, paradigital lesion $(11 / 190)(5.8 \%)$, toe ulcer $(10 / 190)(5.3 \%)$, white line disease $(10 / 190)(5.3 \%)$ and fracture of the distal phalanx (8/190) $(4.2 \%)$, as shown in Table 2.

Table 2: Frequency and amount of dairy cattle affected by podal diseases in the municipality of Jataí/GO from April 2010 to June 2011

\begin{tabular}{ccc}
\hline Disease & $\begin{array}{c}\text { Amount of } \\
\text { animals }\end{array}$ & Frequency (\%) \\
\hline Digital dermatitis (DD) & 45 & 23.7 \\
Septic pododermatitis (SP) & 24 & 12.6 \\
Double sole (DS) & 23 & 12.1 \\
Tiloma (T) & 17 & 8.9 \\
Interdigital dermatitis (ID) & 15 & 7.9 \\
Sole ulcer (SU) & 14 & 7.4 \\
Sole hematoma (SH) & 13 & 6.8 \\
Paradigital lesion (PL) & 11 & 5.8 \\
White line disease (WLD) & 10 & 5.3 \\
Toe ulcer (TU) & 10 & 5.3 \\
Distal phalanx fractures (DPF) & 8 & 4.2 \\
\hline Total & 190 & 100 \\
\hline
\end{tabular}

Similar studies showed that the digital dermatitis was one of the most common podal diseases in dairy cows in the municipalities of Orizona and Jataí, in the State of Goiás (Silva et al., 2001; Rabelo et al., 2006) and in the metropolitan region of the city of Belo Horizonte/MG ${ }^{4}$ (Souza et al., 2007). However, in Northern Brazil, podal diseases such as interdigital hyperplasia, overgrowth of hooves and interdigital necrobacillosis account for more than $90 \%$ of clinical cases of cattle podology (Silveira et al., 2009). It is believed that the difference observed in frequencies of podal diseases in these studies is probably due to epidemiological, climatic and management differences of the regions studied.
Regardless of the podal disease, this work showed that $75.3 \%$ $(143 / 190)$ of hoof lesions occurred in the pelvic limb and $24.7 \%$ $(47 / 190)$ in the thoracic limb $(p<0.05)$. Among the four limbs, the right pelvic limb (RPL) was the most affected one with $51.6 \%$ $(98 / 190)(p<0.05)$ of the diseases diagnosed, followed by the left pelvic limb (LPL) (23.7\%) (45/190), left thoracic limb (LTL) $(13.2 \%)(25 / 190)$ and right thoracic limb (RTL) (11.6\%) (22/190), as shown in Figure 1.

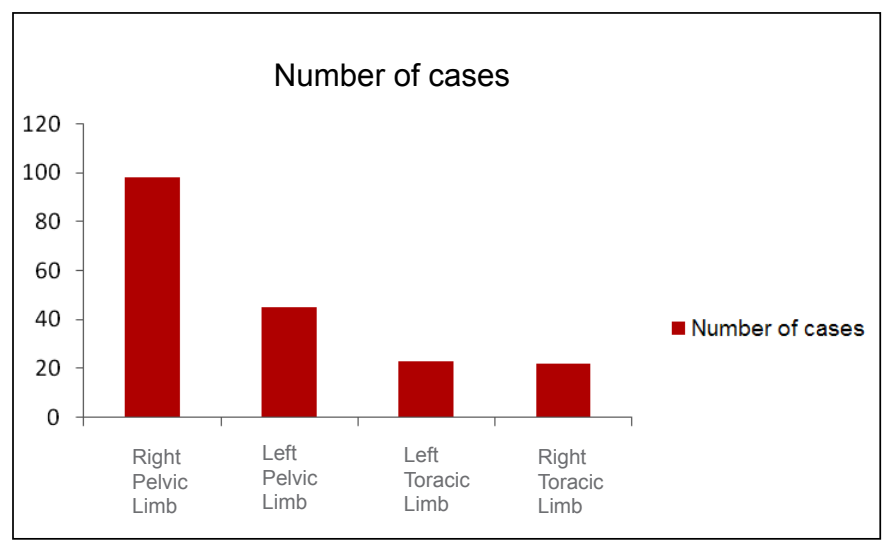

Figure 1: Frequency of podal diseases in 190 dairy cows in the municipality of Jataí/GO according to the limbs affected

Concerning podal diseases diagnosed in the 190 animals, according to the limb affected, it was found that out of the 45 cases of digital dermatitis diagnosed, $55.6 \%$ occurred in the RPL, $24.4 \%$ in the LPL, $11.1 \%$ in the LTL, and $8.9 \%$ in the RTL. In the 24 cases of septic pododermatitis, $45.8 \%$ affected the RPL, $16.6 \%$ the LPL, $20.8 \%$ the LTL and $16.6 \%$ the RTL. In the 23 cases of double sole, $65.1 \%$ occurred in the RPL, $21.7 \%$ in the LPL, $13 \%$ in the LTL and no case occurred in the RTL. The information described above and the frequency of other diseases, according to the limb affected, may be visualized in Figures 2 and 3. In all these podal diseases mentioned previously, the RPL was more affected than the other ones $(p<0.05)$.

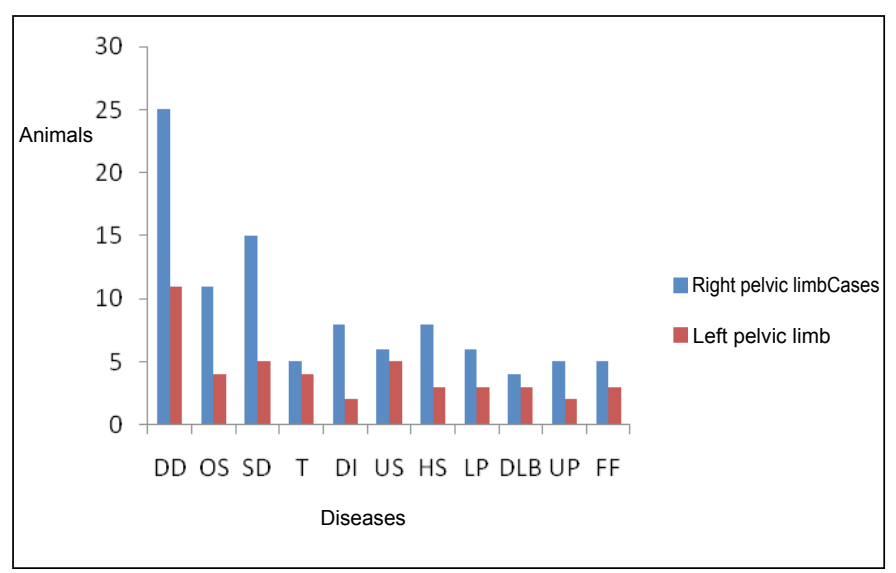

Figure 2: Amount of dairy cattle affected with podal lesions in the municipality of Jataí/GO, distributed according to the pelvic limb affected. DD - Digital dermatitis, SP - Septic pododermatitis, DS - Double sole, T Tiloma, ID - Interdigital dermatitis, SU - Sole ulcer, SH - Sole hematoma, PL - Paradigital lesion, WLD - White line disease, TU - Toe ulcer, PF Phalangeal fracture

\footnotetext{
${ }^{4}$ State of Minas Gerais
} 


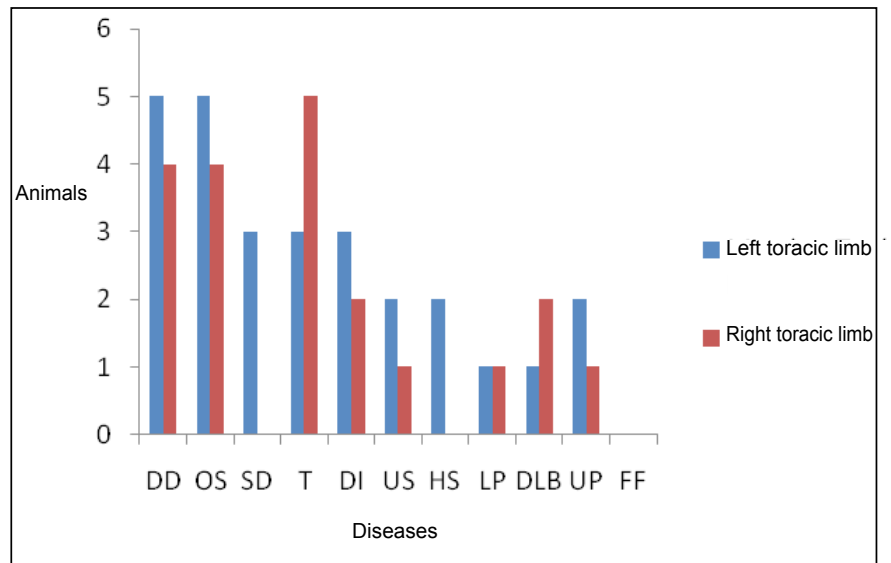

Figure 3: Amount of dairy cattle affected with podal lesions in the municipality of Jataí/GO, distributed according to the thoracic limb affected. DD - Digital dermatitis, SP - Septic pododermatitis, DS - Double sole, T - Tiloma, ID Interdigital dermatitis, SU - Sole ulcer, SH - Sole hematoma, PL - Paradigital lesion, WLD - White line disease, TU - Toe ulcer, PF - Phalangeal fracture

As noticed, the podal lesions occurred more frequently in the pelvic limbs compared to the thoracic ones. These results were associated to multifactorial causes, especially morphofunctional aspects of limbs, both during movement and the sternal decubitus. The greater contamination due to dirtiness, such as urine and stool, is another predisposing factor for higher incidence of lesions in these limbs. These findings are similar to those observed by other authors, who noticed higher incidence of podal lesions in the pelvic limbs of cattle (Vermunt et al., 1995; Silva et al., 2001; Greenough, 2007; Rabelo et al., 2009; Silveira et al., 2009). Endorsing the statements mentioned above, other studies have argued that the ligamentous deficiency of the coxofemoral joint, providing direct contact of the femur with the acetabulum cavity, with consequent impairment in the absorption of impact, would be a major bottleneck to be considered to explain the higher sensitivity of the pelvic limb to podal lesions. Moreover, the insertion of thoracic limbs, performed by muscles, ligaments and tendons softens and minimizes the impact of the podal end on the ground and, thus, reduces the risk of structural damage to the hoof (Vermunt et al., 1995; Nicoletti, 2004; Greenough, 2007). However, studies performed by Oliveira et al. (2007), analyzing the hooves of 1,318 individuals, found digital disease in 350 $(26.6 \%)$ animals, being the interdigital hyperplasia the disease with higher incidence $(21.42 \%)$. They also mentioned that the higher incidence of lesions observed occurred in the thoracic limbs (55.5\%), disagreeing with the findings of this study. These results may suggest that cattle in extensive system are more predisposed to traumatic injuries listed in the forelimb, due to direct contact of this limbs on woody grasses and weeds, justifying the higher occurrence of interdigital hyperplasia. However, additional studies are needed to correlate these findings.

The findings of this study, indicating higher incidence of lesions in the right pelvic limb compared to the left one, are supported by other investigations (Rabelo et al., 2006; Greenough, 2007; Castro et al., 2008; Rabelo et al., 2009). This finding was also attributed to the rest position of the cattle in sternal decubitus, being this position, in most cases, with the right pelvic limb in direct contact to the ground, with possible vascular impairment, which may thus, also endorse the results found.

Regarding the assessment between the podal lesion score and the lameness score, all results may be seen in Table 3.
Table 3: Comparative scores between lesion and lameness of dairy cattle affected by different digital diseases in the municipality of Jatai/GO

\begin{tabular}{|c|c|c|c|c|c|c|c|}
\hline \multirow{2}{*}{ Disease } & \multirow{2}{*}{ Lesion Score } & \multicolumn{5}{|c|}{ Lameness Score } & \multirow[b]{2}{*}{ Tota } \\
\hline & & 0 & 1 & 2 & 3 & 4 & \\
\hline \multirow{3}{*}{ DD } & 1 & 0 & 11 & 2 & 0 & 0 & \\
\hline & 2 & 0 & 9 & 11 & 1 & 0 & 45 \\
\hline & 3 & 0 & 1 & 10 & 0 & 0 & \\
\hline \multirow{3}{*}{ SP } & 1 & 0 & 2 & 0 & 0 & 0 & \\
\hline & 2 & 0 & 4 & 10 & 1 & 0 & 24 \\
\hline & 3 & 0 & 0 & 7 & 0 & 0 & \\
\hline \multirow{3}{*}{ DS } & 1 & 0 & 2 & 10 & 4 & 0 & \\
\hline & 2 & 0 & 0 & 0 & 6 & 0 & 23 \\
\hline & 3 & 0 & 0 & 0 & 0 & 1 & \\
\hline \multirow{3}{*}{$\mathrm{T}$} & 1 & 3 & 7 & 0 & 0 & 0 & \\
\hline & 2 & 1 & 4 & 2 & 0 & 0 & 17 \\
\hline & 3 & 0 & 0 & 0 & 0 & 0 & \\
\hline \multirow{3}{*}{ ID } & 1 & 3 & 5 & 1 & 0 & 0 & \\
\hline & 2 & 0 & 5 & 1 & 0 & 0 & 15 \\
\hline & 3 & 0 & 0 & 0 & 0 & 0 & \\
\hline \multirow{3}{*}{ SU } & 1 & 0 & 0 & 1 & 9 & 0 & \\
\hline & 2 & 0 & 0 & 0 & 4 & 0 & 14 \\
\hline & 3 & 0 & 0 & 0 & 0 & 0 & \\
\hline \multirow{3}{*}{$\mathrm{SH}$} & 1 & 0 & 0 & 2 & 7 & 0 & \\
\hline & 2 & 0 & 0 & 1 & 3 & 0 & 13 \\
\hline & 3 & 0 & 0 & 0 & 0 & 0 & \\
\hline \multirow{3}{*}{$P L$} & 1 & 0 & 0 & 0 & 0 & 0 & \\
\hline & 2 & 5 & 2 & 0 & 0 & 0 & 11 \\
\hline & 3 & 0 & 4 & 0 & 0 & 0 & \\
\hline \multirow{3}{*}{ WLD } & 1 & 0 & 0 & 2 & 7 & 0 & \\
\hline & 2 & 0 & 0 & 0 & 1 & 0 & 10 \\
\hline & 3 & 0 & 0 & 0 & 0 & 0 & \\
\hline \multirow{3}{*}{ TU } & 1 & 0 & 0 & 1 & 6 & 0 & \\
\hline & 2 & 0 & 0 & 0 & 2 & 0 & 10 \\
\hline & 3 & 0 & 0 & 0 & 0 & 1 & \\
\hline \multirow{3}{*}{ PF } & 1 & 0 & 0 & 0 & 0 & 0 & \\
\hline & 2 & 0 & 0 & 0 & 0 & 0 & 08 \\
\hline & 3 & 0 & 0 & 0 & 0 & 8 & \\
\hline $\begin{array}{c}\text { Overall } \\
\text { Total }\end{array}$ & & & & & & & 190 \\
\hline
\end{tabular}

DD - Digital dermatitis, SP - Septic pododermatitis, DS - Double sole, T Tiloma, ID - Interdigital dermatitis, SU - Sole ulcer, SH - Sole hematoma, PL - Paradigital lesion, WLD - White line disease, TU - Toe ulcer, PF Phalangeal fracture

It was found that animals with lesions identified as scores $\mathrm{E} 1$ and $\mathrm{E} 2$, such as sole hematoma, double sole, white line disease and ulcers of the sole and toe, in many situations presented score 2 and 3 lameness, noticing severe discomfort for the animal and, therefore, greater impact on production (Figure 4). 


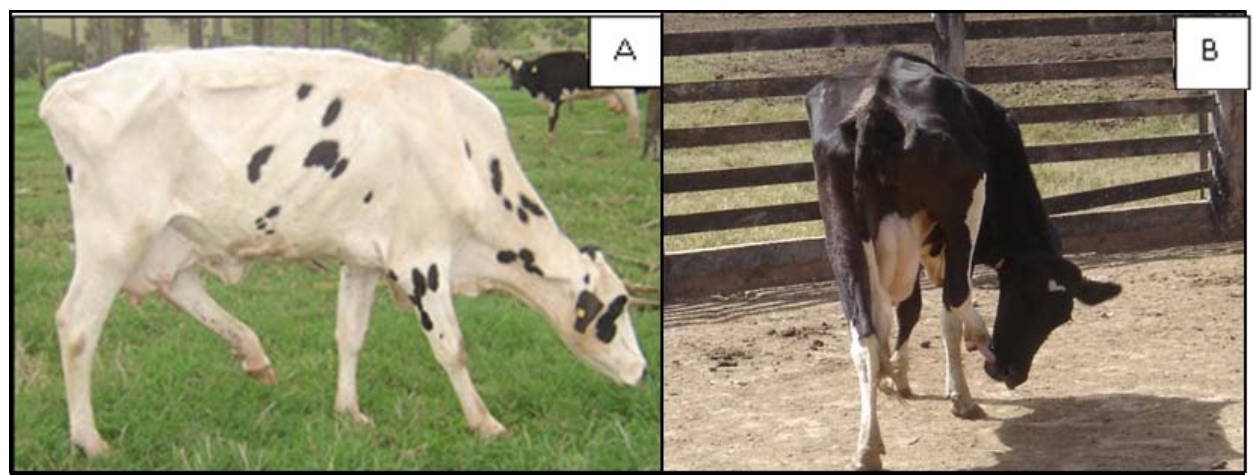

Figure 4: Animals affected by podal diseases classified as E1 to the lesion severity, being degree 3 (A) elevation lameness evidenced, in addition to intense pruritus (B)

In some animals diagnosed with score E2 and E3 lesions, such as cases of digital dermatitis, tiloma, paradigital lesion and septic pododermatitis, score 1 and 2 lameness was noticed. Figure 5 illustrates different types of diseases and lesion score relating them to the scores of lameness presented by the injured animal.

There was no correlation between the podal lesion score and the lameness score ( $r s=0.0694$ ), thus such correlation was not significant $(p>0.05)$. Such information disagrees, in part, with other studies (Vermunt et al., 1995; Smith, 2001; Greenough, 2007) which mention that lameness is directly related to the extension of the hoof lesion and that diseases such as digital dermatitis, once they determine the intense reaction of pain and pruritus, are responsible for severe lameness, such facts not observed in this study.

\section{Conclusions}

In this study, digital injuries considered serious are not always responsible for pronounced lameness. There was no correlation between the podal lesion score and the lameness score, thus such correlation was not significant and this information disagrees, in part, with other studies. New studies with a larger number of animals should be conducted in order to clarify these questions.

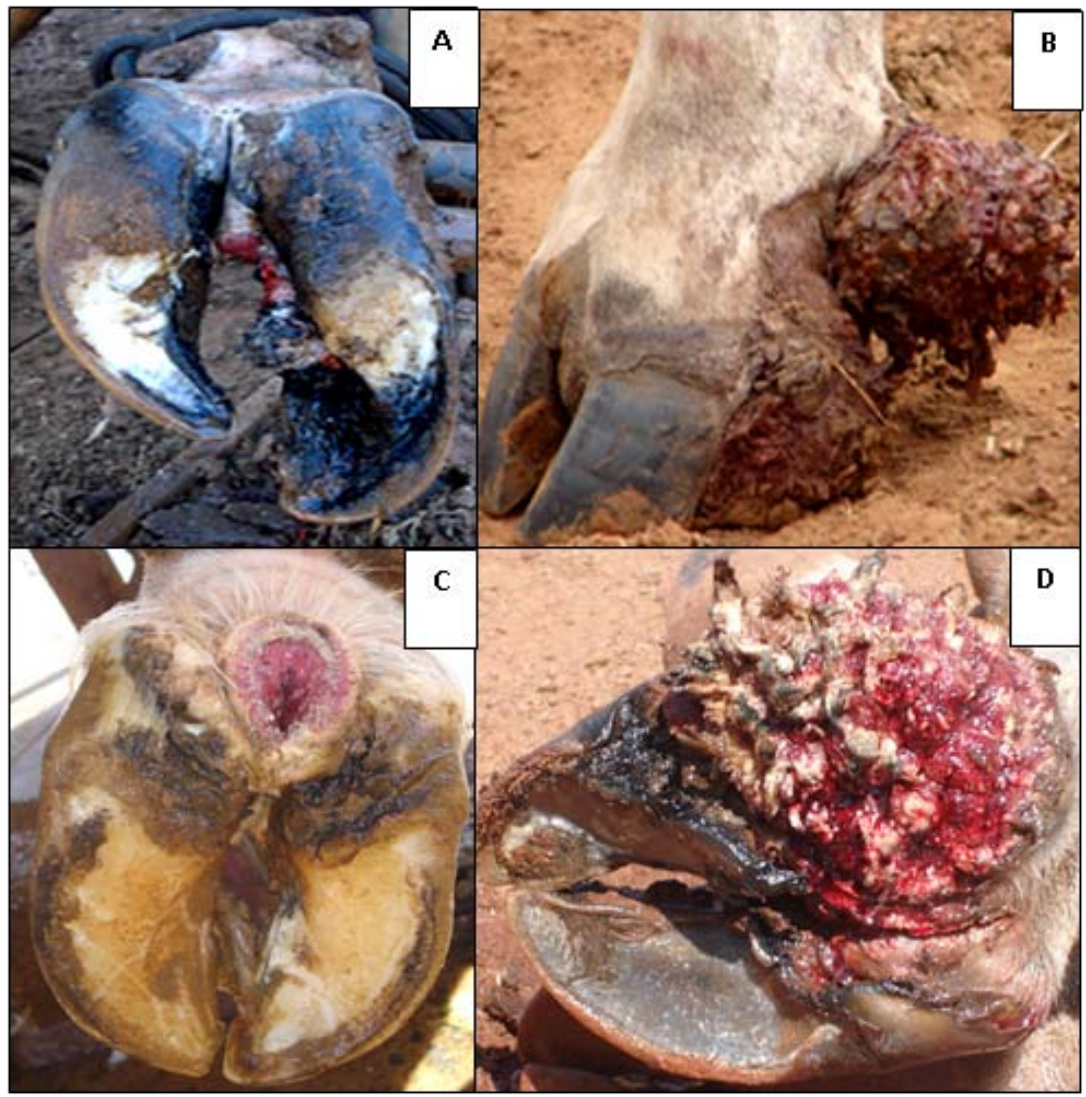

Figure 5: Cattle affected by different types of podal disease: (A) Septic pododermatitis, (B) Paradigital lesion, (C) Digital dermatitis in early or erosive stage, (D) Digital dermatitis with verrucous or proliferative aspect. The lesions were classified, respectively, in the lesion score as E3, E3, E2 and E3, with score 2 for lameness in all cases 


\section{References}

BLOWEY, R.W.;WEAVER, A.D. Color atlas of diseases and disorder of cattle. 2. ed. Mosby, Philadelphia, 2006, p. 82-122.

BORGES, J.R.J.; PITOMBO, C.A.; SANTIAGO, S.S.; RIBEIRO, P.N; RONCONI, M.A. Incidência de afecçõ es podais em bovinos leiteiros submetidos a diferentes sistemas de manejo. Arquivos da Escola de Medicina Veterinária da Universidade Federal da Bahia, v.15, p.34-42, 1992.

CASTRO, G.R. Estudo anatomopatológico de lesões de dermatite digital em bovinos. Ciência Animal Brasileira, v .9, n. 4, p.11591166, 2008.

CRUZ, C.E.F.; DRIEMEIER, D.; CERVA, C.; CORBELLINI L. G. Clinical and epidemiological aspects of bovine digital lesions in Southern Brazil. Arquivos Brasileiros de Medicina Veterinária e Zootecnia, v.53, n. 6, p. 654-657, 2001.

DEMIRKAN,I.; MURRAY, R.D.; CARTER, S.D. Skin diseases of the bovine digit associated with lameness. Veterinary Bulletin, v.70, n. 2, p.149-171, 2000.

FRANCK, A.; VERHEGGHE, B.; DE BELIE, N. The effect of concrete floor roughness on bovine claws using finite element analysis. Journal of Dairy Science, v .91, p.182-192, 2008.

GREENOUGH, P. R. Bovine laminitis and lameness - A hands-on approach. Saunders Elsevier, Philadelphia, 2007. 311 p.

MOLINA, L.R.; CARVALHO, A.U.; FACURY FILHO, E.J.; FERREIRA, P.M. Prevalência e classificação das afecções podais em vacas lactentes na bacia leiteira de Belo Horizonte. Arquivos Brasileiros de Medicina Veterinária e Zootecnia, v. 51, n. 2, p. 149152, 1999.

NICOLETTI, J.L.M. Manual de Podologia Bovina. Manole, Barueri, 2004. 125 p.

OLIVEIRA, D.R.; VIANA, R.B.; ARAÚJO, C.V.; MONTEIRO, B.M. Ocorrência de lesões podais em bovinos de corte e bubalinos abatidos no Estado do Pará. Archives of Veterinary Science, v.12, (suppl.) (Summary). 2007.

RADOSTITS, O.M.; MAYHEW, I.G.J.; HOUSTON, D.M. Exame clínico e diagnóstico em veterinária. Guanabara Koogan, Rio de Janeiro, 2002. 519-569 p.

RABELO, R.E.; KANASHIRO, T.C.; PARREIRA, C.A.; LIMA, C R.O.; OLIVEIRA, S.L. Aspectos epidemiológicos, diagnóstico e tratamento das principais enfermidades que acometem o rebanho bovino leiteiro no município de Jataí-GO. In: CONBRAVET, 33, 2006. Anais... Cuiabá, CONBRAVET, 2006.
RABELO, R.E.; ALVES, J.F.; LIMA, C.R.O.; REIS, E.F.; BAYLÃO, M.L.; RODRIGUES, E.O.; CARVALHO, F.C.; BANNWART, L.F. Identificação e caracterização de diferentes digitais acometendo bovinos leiteiros do município de Jataí-GO e sua influência na claudicação. In: CONBRAVET, 36. 2009. Anais... Porto Seguro, CONBRAVET, 2009.

RODRIGUES, C.A.; LUVIZOTTO, M.C.R.; ALVES, A.L.G.; TEODORO, P.H.M.; GREGÓRIO, E.A. Digital dermatitis of the accessory digits of dairy cows. Pesquisa Veterinária Brasileira, v. 30, n. 3, p. 246-248, 2010.

ROMANI, A.F.; SILVA, L.A. F.; FIORAVANTI, M.C.S.; RABELO, R.E.; CUNHA, P.H.J.; AMARAL, A.V.C.; VERÍSSIMO, A.C.C.; SILVA, E.B. Ocorrência de lesões podais em fêmeas bovinas leiteiras no Estado de Goiás. ARS Veterinária, v. 20, n. 3, p. 322329, 2004.

SAMPAIO, I.B.M. Estatística aplicada à experimentação animal. 3ed. FEPMVZ, Belo Horizonte, 2007. 264 p.

SAS. SAS/STAT User's Guide (Release 9.0). SAS Institute Inc., Cary, NC, 2002.

SILVA, L.A.F.; SILVA, L.M.; ROMANI, A.F.; RABELO, R.E.; FIORAVANTI. M.C.S.; SOUZA, T.M.; SILVA, C.A. Características clínicas e epidemiológicas das enfermidades podais em vacas lactentes do município de Orizona - GO. Ciência Animal Brasileira, v. 2, p. 119-126, 2001

SILVA, L.A. F.; SILVA, C.A.; BORGES, J.R.J.; FIORAVANTI, M.C.S.; BORGES, G.T.; ATAYDE, I.B. A clinical trial to assess the use of sodium hypochlorite and oxytetracycline on the healing of digital dermatitis lesions in cattle. Canadian Veterinary Journal, v. 46, n. 4, p. 345-348, 2005.

SILVEIRA, J.A.S.; ALBERNAZ, T.T.; OLIVEIRA, C.M.C.; DUARTE, M.D.; BARBOSA, J.D. Afecções podais em vacas da bacia leiteira de Rondon do Pará. Pesquisa Veterinária Brasileira, v. 29, n.11, p. 905-909, 2009.

SMITH, R.A. The Veterinary Clinic of North America. Saunders, Philadelphia, 2001. 229 p.

SOUZA, R.C.; CARVALHO, A.U.; FERREIRA, P.M.; FACURY FILHO, E.J.; FERREIRA, R.G.; COSTA, C.O.; MOURTHE NETO, A. Prevalência e distribuição de lesões digitais em vacas leiteiras nas regiões de Belo Horizonte e Pedro Leopoldo. Ciência Animal Brasileira, v. 8, n. 4, p. 823-831, 2007.

VERMUNT, J.J.; GREENOUGH, P.R. Structural characteristics of the bovine claw: horn growth and wear, horn hardness and claw conformation. British Veterinary Journal, v. 151, p. 157-180, 1995. 